\title{
A Preliminary Study of Nutritional Quality of Five Drought Tolerant Millets
}

\author{
Olamide S. Antonio Ajibona ${ }^{1}$, Adedolapo Ajiboma Idowu ${ }^{1}$, A. A. Hamama ${ }^{1} \&$ Harbans L. Bhardwaj $^{1}$ \\ ${ }^{1}$ Agricultural Research Station, Virginia State University, Petersburg, VA, USA \\ Correspondence: Harbans L. Bhardwaj, Agricultural Research Station, Virginia State University, Petersburg, VA \\ 23806, USA. Tel: 1-804-524-6723. Fax: 1-804-524-5950. E-mail: hbhardwaj@vsu.edu
}

Received: February 19, 2021

Accepted: March 21, $2021 \quad$ Online Published: April 15, 2021

doi:10.5539/jas.v13n5p76

URL: https://doi.org/10.5539/jas.v13n5p76

The research was financed by Virginia State University and US Department of Agriculture (NIFA/Evans-Allen Program).

\begin{abstract}
Seeds from greenhouse-grown plants of five food millet crops-[barnyard millet (Echinochloa frumentacea Link.), finger millet (Eleusine coracana Gaertn.), kodo millet (Paspalum scrobiculatum L.), little millet (Panicum sumatrense Roth ex Roem. \& Schult.), and proso millet (Panicum miliaceum L.)] contained 10.4, 5.5, 7.2, 1.3, and 17.1 percent protein; 69, 29, 239, 105, and $32 \mathrm{Fe}(\mathrm{mg} / 100 \mathrm{~g})$; and 33, 22, 23, 31, and 37 (mg/100 g) $\mathrm{Zn}$, respectively. Concentrations $(\mathrm{g} / 100 \mathrm{~g})$ of oil in seeds varied from 1.32 for finger millet to 3.58 for little millet. The oil concentrations for barnyard, kodo, and proso millets were 1.59, 1.64, and $3.36 \mathrm{~g} / 100 \mathrm{~g}$, respectively. Predominant fatty acid in the oil in the seed of these millets was C18:2 followed by C18:1, and C16:0. Concentration of omega-3 fatty acid (a heart-healthy oil) was 1.06, 0.62, 1.01, 0.91, and $3.11 \mathrm{~g} / 100 \mathrm{~g}$ in barnyard, kodo, little, proso, and finger millet, respectively. Oils from seeds of these millet crops were essentially free from concentration of anti-nutritive fatty acid C22:1 (Erucic acid). Concentrations (g/100 g) of total sugars varied from 0.96 for barnyard millet to 2.09 for finger millet. The total sugar concentrations for kodo, little, and proso millets were $1.81,1.95$, and $1.99 \mathrm{~g} / 100 \mathrm{~g}$, respectively. Fructose, glucose, sucrose, maltose, raffinose, and stachyose concentrations varied from 0.05 to $0.47,0.44$ to $0.85,0.44$ to $0.98,0.02$ to $0.33,0.005$ to 0.083 , and 0.002 to 0.053 , respectively for barnyard, kodo, little, proso, and finger millet, respectively. Results indicated that these millet crops have potential as sources of healthy food and it might be worthwhile to further study their production potential.
\end{abstract}

Keywords: barnyard millet, finger millet, kodo millet, little millet, proso millet, protein concentration, oil concentration, fatty acids, sugars, new crops

\section{Introduction}

Increasing world population and droughts are a concern for global food supplies. A report by United Nations (https://www.un.org/en/sections/issues-depth/population/index.html) states that "In 1950, five years after the founding of the United Nations, world population was estimated at around 2.6 billion people. It reached 5 billion in 1987and 6 billion in 1999. In October 2011, the global population was estimated to be 7 billion. The world's population is expected to increase by 2 billion persons in the next 30 years, from 7.7 billion currently to 9.7 billion in 2050 and could peak at nearly 11 billion around 2100.

Given that drought stress may reduce more than $50 \%$ of the average crop yield and can further limit agriculture productivity, special attention must be given to agricultural research, extension services and development in order to attain the required agricultural yield and productive gains. To counter the effect of future food crises and drought stress, we have to design and grow crops that are rich in proteins, fibers and essential nutrients to overcome malnutrition and food-related diseases (Dubey et al., 2019).

To improve abiotic stress, particularly drought, tolerance of cereals is of extreme importance as cereals including wheat and barley are the main constituents of the world food supply (Sinclair, 2011). However, several minor crops, such as millets, are potential candidates for supplying nutritious food. A publication of the Millet Network of India_-Deccan Development Society_FIAN, India (Anonymous, 2007) indicates that millets need very little 
water for their production. Compared to irrigated commodity crops, millets require just around $25 \%$ of the rainfall regime and grow well on skeletal soils that are less than $15 \mathrm{~cm}$ deep and can be a boom for dryland areas. Millets are known to have excellent nutrition content being three to five times nutritionally superior to the widely promoted rice and wheat in terms of proteins, minerals and vitamins. This publication lists barnyard millet, finger millet, kodo millet, little millet, and proso millet as "climate change compliant crops". Climate change portends less rain, more heat, reduced water availability and increased malnutrition.

The current study was conducted as a first step towards introduction/establishment of several millets in the mid-Atlantic region of the United States of America. The specific objective was to characterize nutritional quality of locally-grown barnyard millet, finger millet, kodo millet, little millet, and proso millet.

\section{Materials and Methods}

\subsection{Plant Material}

We conducted a preliminary experiment by growing five millet crops (barnyard millet, kodo millet, little millet, proso millet, and finger millet) to characterize their growth especially their nutritional quality. Seeds for planting were purchased from a grocery store.

\subsection{Production}

All five millets were grown in a greenhouse located on Randolph Farm of Virginia State University $\left(37^{\circ} 15^{\prime} \mathrm{N}\right.$ and $077^{\circ} 30.8^{\prime} \mathrm{W}$ ) using a completely randomized design. Each millet (approximately 20-30 seeds per pot) was planted in two $30 \mathrm{~cm}$ tall plastic pots filled with growing material (Promix-BX, https://www.pthorticulture.com/ en/products/pro-mix-bx/). The seeds were spread on top of the growing material and then covered lightly. All pots were placed in water trays and were bottom watered. These plantings were done on April 1, 2019. Greenhouse temperature was maintained from 75 to $90^{\circ} \mathrm{F}$. Upon germination, the pots were thinned to 2-3 plants per pot. Seeds were harvested as they natured starting about 120 days after planting.

\subsection{Analysis of Seed Composition for Concentrations of Fatty Acids and Sugars}

Seeds from all five millets were used for nutritional quality analyses. Mineral concentrations, including nitrogen $(\mathrm{N})$, in seed were determined according to AOAC methods (AOAC, 2016) by Waypoint Analytical Laboratory (Richmond, Virginia, USA). Total protein concentration was calculated by multiplying $\mathrm{N}$ content with protein factor 6.25 .

The oil concentration was determined in the Common Laboratory of Agricultural Research Station of Virginia State University. The oil was extracted from ground millet seeds $(5 \mathrm{~g})$ three times at room temperature by homogenization for $2 \mathrm{~min}$ in $20 \mathrm{~mL}$ hexane/isopropanol (3:2, v/v) with a Biospec Model 985-370 Tissue Homogenizer (Biospec Products, Inc. Racine, WI, USA) and centrifuged at $4000 \mathrm{~g}$ for $5 \mathrm{~min}$, as described by Hamama et al. (2003). The three extractions were combined and the hexane-lipid layer was separated from the combined extract after shaking with $10 \mathrm{~mL}$ of $1 \%$ solution of equal amounts of $\mathrm{CaCl}_{2}$ and $\mathrm{NaCl}$ in $50 \%$ methanol. The hexane lipid layer was removed by aspiration and dried over anhydrous Na2SO4. The oil percentage ( $\mathrm{g} / 100 \mathrm{~g}$ dry basis) was determined gravimetrically after drying under vacuum at $40{ }^{\circ} \mathrm{C}$ and stored under nitrogen at $-10{ }^{\circ} \mathrm{C}$ until analysis.

Sugars were extracted from ground seed samples of each millet $(1 \mathrm{~g})$ and analyzed by HPLC following the methods optimized by Johansen et al. (1996). Sugars in the extracts were identified by comparing their retention times with standard sugars. For quantification, trehalose was used as internal standard and the sugar concentration was expressed as g/100 g meal (Bhardwaj \& Hamama, 2016).

\subsection{Data Analysis}

All data were analyzed using version 9.1 of SAS (SAS Institute, Inc., 2014) using ANOVA with $5 \%$ level of significance.

\section{Results and Discussion}

Our study is an attempt to address issues related to climate change and increasing droughts. Climate change, global warming, and related increase in droughts are already having comparable effects on the efficiency in food production as well as on its quality worldwide (FAO, 2019). The climate change and droughts are expected to significantly affect the duration and quality of the growing season and with increasing drought could cause damage to crops and food production (Gomez-Zavaglia et al., 2020). It has been suggested that mitigation of drought-related problems could be achieved via developing new agricultural practices, introducing other crops and animal varieties, and applying the principles of integrated pest management. Several strategies for crop and 
livestock have been devised to increase their resilience to extreme climate. Therefore, crops can be managed by breeding for drought and temperature tolerance and selecting appropriate cultivars (Sofi et al., 2019).

All five millets included in our study germinated and established a stand. The best germination and stand establishment was observed for finger millet (about 80 percent) whereas corresponding values for other four millets were about 30 to 50 percent. All five millets produced some seed-finger millet produced the most seed. Seeds were harvested from all millets starting about 120 days after planting. All seeds of each millet from all pots were bulked and used or chemical composition analyses. The experiment was successfully completed.

Table 1. Composition of seeds of barnyard, kodo, little, proso, and finger millet grown in greenhouse during 2019

\begin{tabular}{|c|c|c|c|c|c|}
\hline Trait & Barnyard & Kodo & Little & Proso & Finger \\
\hline Protein (\%) & 10.4 & 7.25 & 1.3 & 17.1 & 5.50 \\
\hline Oil (\%) & 1.59 & 1.64 & 3.58 & 3.36 & 1.32 \\
\hline P (\%) & 0.20 & 0.16 & 0.28 & 0.33 & 0.27 \\
\hline K (\%) & 0.21 & 0.16 & 0.22 & 0.29 & 0.58 \\
\hline $\mathrm{Ca}(\%)$ & 0.05 & 0.04 & 0.05 & 0.04 & 0.32 \\
\hline $\operatorname{Mg}(\%)$ & 0.11 & 0.08 & 0.18 & 0.17 & 0.18 \\
\hline S (\%) & 0.14 & 0.12 & 0.15 & 0.18 & 0.12 \\
\hline $\mathrm{Al}(\mathrm{mg} / 100 \mathrm{~g})$ & 9.00 & 41.0 & 12.0 & 8.00 & 9.00 \\
\hline $\mathrm{B}(\mathrm{mg} / 100 \mathrm{~g})$ & 1.00 & 1.00 & 1.00 & 1.00 & 1.00 \\
\hline $\mathrm{Cu}(\mathrm{mg} / 100 \mathrm{~g})$ & 7.00 & 11.0 & 8.00 & 11.0 & 9.00 \\
\hline $\mathrm{Fe}(\mathrm{mg} / 100 \mathrm{~g})$ & 69.0 & 239 & 105 & 32.0 & 29.0 \\
\hline $\mathrm{Mn}(\mathrm{mg} / 100 \mathrm{~g})$ & 23.0 & 15.0 & 14.0 & 15.0 & 349 \\
\hline $\mathrm{Na}(\mathrm{mg} / 100 \mathrm{~g})$ & 0.01 & 0.01 & 0.01 & 0.01 & 0.01 \\
\hline $\mathrm{Zn}(\mathrm{mg} / 100 \mathrm{~g})$ & 33.0 & 23.0 & 31.0 & 37.0 & 22.0 \\
\hline \multicolumn{6}{|c|}{ Saturated fatty acids (percentage of total fatty acids) } \\
\hline $\mathrm{C} 14: 0$ & 0.08 & 0.08 & 0.04 & 0.03 & 0.06 \\
\hline $\mathrm{C} 15: 0$ & 0.04 & 0.02 & 0.02 & 0.02 & 0.07 \\
\hline $\mathrm{C} 16: 0$ & 17.40 & 16.95 & 15.63 & 7.53 & 23.46 \\
\hline C18:0 & 4.68 & 3.20 & 5.52 & 1.85 & 2.25 \\
\hline C20:0 & 0.89 & 1.19 & 0.95 & 0.81 & 0.37 \\
\hline $\mathrm{C} 22: 0$ & 0.26 & 0.46 & 0.24 & 0.57 & 0.20 \\
\hline $\mathrm{C} 24: 0$ & 0.04 & 0.05 & 0.01 & 0.01 & 0.01 \\
\hline $\mathrm{TS}^{1}$ & 23.4 & 21.9 & 22.4 & 10.8 & 26.4 \\
\hline \multicolumn{6}{|c|}{ Unsaturated fatty acids (percentage of total fatty acids) } \\
\hline C15:1 & 0.01 & 0.02 & 0.01 & 0.02 & 0.04 \\
\hline C16:1 & 0.32 & 0.16 & 0.26 & 0.14 & 0.40 \\
\hline C18:1 & 29.45 & 38.83 & 35.55 & 25.16 & 46.98 \\
\hline C18:2 & 45.23 & 37.75 & 40.12 & 61.96 & 24.48 \\
\hline C18:3 & 1.06 & 0.62 & 1.01 & 0.91 & 3.11 \\
\hline C20:1 & 0.33 & 0.53 & 0.40 & 0.72 & 0.38 \\
\hline C20:2 & 0.06 & 0.03 & 0.01 & 0.04 & 0.01 \\
\hline C20:3 & 0.02 & 0.04 & 0.03 & 0.06 & 0.05 \\
\hline C20:5 & 0.06 & 0.01 & 0.06 & 0.02 & 0.06 \\
\hline C22:1 & 0.03 & 0.03 & 0.08 & 0.05 & 0.04 \\
\hline C24:1 & 0.06 & 0.07 & 0.09 & 0.13 & 0.05 \\
\hline TUS $^{1}$ & 76.6 & 78.1 & 77.6 & 89.2 & 75.6 \\
\hline \multicolumn{6}{|c|}{ Sugars (percentage based on dry weight basis) } \\
\hline Fructose & 0.048 & 0.04 & 0.473 & 0.131 & 0.347 \\
\hline Glucose & 0.445 & 0.838 & 0.606 & 0.523 & 0.680 \\
\hline Sucrose & 0.439 & 0.569 & 0.705 & 0.930 & 0.978 \\
\hline Maltose & 0.024 & 0.176 & 0.113 & 0.329 & 0.042 \\
\hline Raffinose & 0.005 & 0.083 & 0.002 & 0.050 & 0.026 \\
\hline Stachyose & 0.002 & 0.047 & 0.053 & 0.027 & 0.021 \\
\hline Total sugars & 0.962 & 1.806 & 1.951 & 1.991 & 2.095 \\
\hline
\end{tabular}

Note. ${ }^{1}: \mathrm{TS}=$ total saturated fatty acids; TUS $=$ total unsaturated fatty acids. 
Composition of seeds of five millet crops under study are presented in Table 1. Seeds of proso millet contained most protein (17.1 percent) whereas seeds of little millet contained only 1.3 percent protein. Protein concentration in barnyard, kodo, and finger millet contained 10.4, 7.25, and 5.50 percent protein. Kodo millet seeds were observed to considerable concentrations of aluminum and iron (41.0 and $239 \mathrm{mg} / 100 \mathrm{~g}$, respectively whereas proso millet seeds contained considerable concentration of zinc and finger millet contained considerable concentration of magnesium $(349 \mathrm{mg} / 100 \mathrm{~g})$. Seeds of all five millets contained negligible concentrations of sodium. Fe concentrations (mg/100 g) were 69, 29, 239, 105, and 32; and Zn concentrations (mg/100 g) were 33, $22,23,31$, and 37 , respectively for barnyard, finger, kodo, little, and proso millets.

Barnyard, kodo, little, and finger millet seeds from India have been reported to contain 7 to 13,6 to 11,8 to 11,5 to 6 percent protein, respectively (Chandel et al., 2014). In comparison, protein concentrations from our study were, generally, similar to those from India except for little millet which only contained 1.3 percent protein. Similarly, Zn concentration in our study was comparable to those from India for these millets (36 to 40, 20 to 24 , 30 to 33 , and 21 to $28 \mathrm{mg} / 100 \mathrm{~g}$ ). However, seeds of millets in our study contained considerable higher concentrations of $\mathrm{Fe}$ in comparison to those from India reported to be 20 to 45, 20 to 24, 30 to 33, and 21 to 28 $\mathrm{mg} / 100 \mathrm{~g}$, respectively (Chandel et al., 2014).

Seeds of all five millet crops contained some oil. The oil concentration varied from 1.32 (finger millet) to 3.58 (little millet) percent. Oil concentrations in seeds of barnyard, kodo, and proso millets were 1.59, 1.64, and 3.36 percent, respectively. Predominant saturated fatty acids in seeds of all five millets were C16:0, C18:0, C20:0, and $\mathrm{C} 22: 0$ in descending order. Predominant unsaturated fatty acids in seeds of barnyard, little, and proso millet was C18:2 whereas that in kodo and finger millet seeds was C18:1. Concentration of heart-healthy Omega-3 fatty acid (percentage of total fatty acids) in seeds of five millets varied from 0.62 (kodo millet) to 3.11 (finger millet). Concentrations of this fatty acid in barnyard, little, and proso millets were $1.06,1.01$, and 0.91 percent, respectively. Duke and Ayensu (1985) reported that finger millet, generally, contains 1.5 percent fat in comparison to 1.32 percent in our study. Heuze and Tran (2015) reported the oil content in millet seeds as 1.9 percent in finger millet, 1.5 percent in kodo millet, 1.5 percent in little millet, 5.6 percent in proso millet, and 6 percent in barnyard millet.

Sugar concentration (percentage on dry weight basis) in seeds of varied from 0.96 (barnyard millet) to 2.09 (finger millet). Sugar concentrations in kodo, little, and proso millet seeds were 1.81, 1.95, and 1.99, respectively. Two predominant sugars in seeds of five millet crops in this study were glucose and sucrose. Glucose and sucrose concentrations in barnyard, kodo, little, proso, and finger millet seeds, respectively, were $0.44,0.84,0.61$, 0.52 , and $0.68 ; 0.44,0.57,0.70,0.93$, and 0.98 . Heuze and Tran (2015) reported sugar concentrations in barnyard, kodo, little, an proso millet seeds as 1.9, 1.4, 1.4, and 1.9 percent, respectively. Concentrations in seeds of finger millet from our study were, generally, lower than those reported by Wankhede et al. (1979).

Our results are preliminary and would need to be substantiated and expanded to include other seed constituents. However, a preliminary review indicates that the five millet crops under study have potential to provide healthy food.

\section{Conclusions}

Results of this preliminary study indicate that barnyard, kodo, little, proso, and finger millets have potential as sources of healthy food. As these crops are previously well known as drought tolerant, it may be desirable to further study their production potential in the mid-Atlantic region of the United States of America. We are encouraged by the observation of Ugare et al. (2014) indicating that most millets are nutritionally superior to cereals and can yield food and forage in a short duration and at low inputs even under adverse climatic conditions.

\section{Disclaimer}

This study was conducted as a student training project for the first two authors. Use of any trade names or vendors does not imply approval to the exclusion of other products or vendors that may also be suitable.

\section{References}

Anonymous. (2007). Millets: Future of Food and Farming. Retrieved from https://milletindia.org/wp-content/ uploads/2015/07/Milletsfutureoffoodandfarming.pdf

AOAC (Association of Official Analytical Chemists). (2016). Official Methods of Analysis (20th ed.). AOAC, Arlington, VA. Retrieved from http://www.aoac.org/aoac_prod_imis/AOAC/AOAC_Member/PUBSCF/ OMACF/OMAP_M.aspx 
Bhardwaj, H. L., \& Hamama, A. A. (2016). Cultivar, planting date, and row spacing effects on Mungbean seed composition. Journal of Agricultural Science, 8, 26-32. https://doi.org/10.5539/jas.v8n10p26

Chandel, G., Meena, R. K., Dubey, M., \& Kumar, M. (2014). Nutritional properties of minor millets: Neglected cereals with potentials to combat malnutrition. Current Science, 107, 1109-1111. Retrieved from https://www.jstor.org/stable/24105623

Dubey, A., Kumar, A., Abd Allah, E. F., Hashem, A., \& Khan, M. L. (2019). Growing more with less: Breeding and developing drought resilient soybean to improve food security. Ecological Indicators, 105, 425-437 https://doi.org/10.1016/j.ecolind.2018.03.003

Duke, J. A., \& Ayensu, E. S. (1985). Medicinal Plants of China. Reference Publications, Inc.

FAO (Food and Agriculture Organization of the United Nations). (2019). The state of food security and nutrition in the world. Safeguarding against economic slowdowns and downturns. FAO, Rome.

Gomez-Zavaglia, A., Mejuto, J. C., \& Simal-Gandara, J. (2020). Mitigation of emerging implications of climate change on food production systems. Food Research International, 134, 109256. https://doi.org/10.1016/ j.foodres.2020.109256

Hamama, A. A., Bhardwaj, H. L., \& Starner, D. E. (2003). Genotype and growing location effects on phytosterols in canola oil. Journal of AOCS, 80, 1121-1126. https://doi.org/10.1007/s11746-003-0829-3

Heuzé, V., \& Tran, G. (2015). Finger millet (Eleusine coracana), grain. Feedipedia, a programme by INRAE, CIRAD, AFZ and FAO. Retrieved May 11, 2015, from https://feedipedia.org/node/721

Johansen, H. N., Gilts, V., \& Knudsen, K. E. N. (1996). Influence of Extraction Solvent and Temperature on the Quantitative Determination of Oligosaccharides from Plant Materials by High-Performance Liquid Chromatography. J. Agric. Food Chem., 44, 1470-1474. https://doi.org/10.1021/jf950482b

SAS. (2014). SAS for Windows Version 9.4. SAS Institute, Cary, N.C. Retrieved from http://www.sas.com/ en_us/software/sas9.html

Sinclair, T. R. (2011). Challenges in breeding for yield increase for drought. Trends in Plant Science, 16(6), 289-293. https://doi.org/10.1016/j.tplants.2011.02.008

Sofi, P. A., Ara, A., Gull, M., \& Rehman, K. (2019). Canopy temperature depression as an effective physiological trait for drought screening. Drought—Detection and Solutions. Gabrijel Ondrasek, Intechopen. https://doi.org/10.5772/intechopen.85966

Ugare, R., Chimmad, B., Naik, R., Bharati, P., \& Itagi, S. (2014). Glycemic index and significance of barnyard millet (Echinochloa frumentacae) in type II diabetics. J Food Sci Technol, 51(2), 392-395. https://doi.org/10.1007/s13197-011-0516-8

Wankhede, D.B., A. Shehnaj, and M.R. R. Rao. 1979. Carbohydrate composition of finger millet (Eleusine coracana) and foxtail millet (setaria italica). Qualitas Plantarum, 28, 293-303. https://doi.org/ 10.1007/BF01095511

\section{Copyrights}

Copyright for this article is retained by the author(s), with first publication rights granted to the journal.

This is an open-access article distributed under the terms and conditions of the Creative Commons Attribution license (http://creativecommons.org/licenses/by/4.0/). 